\title{
Teachers' first year in the profession: The power of high-quality support
}

In research on teacher induction, scholars have pointed at the pivotal role of collegial support to overcome the challenges inherent to the first years of teaching. In this quantitative study, we extend current work by using a social network perspective to examine characteristics (i.e. network size, frequency and perceived usefulness) of professional, emotional, and social collegial support networks. Moreover, we explore the extent to which these characteristics explain key factors affecting teacher retention, namely job satisfaction, intrinsic motivation to teach, and self-efficacy. An online survey was completed by 292 beginning primary school teachers in Flanders (Belgium). Social network data showed that, on average, they receive professional, emotional and social support from six colleagues each week and found this mostly useful. Regression analyses demonstrated that network size and perceived usefulness of professional, emotional, and social collegial support networks were positively related to job satisfaction and intrinsic motivation to teach, thus confirming the importance of collegial support in teacher induction. Frequency of support was not significant. Finally, no substantial relationship was found between collegial support and teachers' selfefficacy. Implications of these findings for practice and policy are discussed.

Keywords: beginning teachers; teacher induction period; collegial support; social network perspective

Cite as follows: Thomas, L., Tuytens, M., Moolenaar, N., Devos, G., Kelchtermans, G., \& Vanderlinde, R. (2019). Teachers' first year in the profession: the power of high-quality support. Teachers and Teaching: Theory and Practice.

Disclaimer: Please note that this version may still slightly differ from the final print version. 


\section{Introduction}

In recent decades, educational research literature has acknowledged that professional development is a lifelong process of learning and developing (Day, 1999; Author, 1993; author et al., 2016d), in which teachers have different professional needs in each career phase. One of these phases is the teacher induction period whereby professional development is particularly intensive (Author et al., 2002). Across the world, numerous teachers exit the profession during this phase (Ingersoll \& Strong, 2011), a phenomenon commonly labelled as the 'Teacher Retention Crisis' (Hunt et al., 2003). In the US and the UK, 30\% to 50\% of all teachers leave the profession during the first five years (Cooper \& Alvarado, 2006). In Flanders (Belgium), where this study took place, approximately one in five secondary teachers and one in seven primary teachers drop out within the first five years (Flemish Department of Education and Training, 2013). These high drop-out rates have been recognised as one of the causes of teacher shortages (Ingersoll \& Strong, 2011) with a potentially negative impact on student performance (Ingersoll, 2001). This underlines the need to tackle the teacher retention crisis (OECD, 2005).

Collegial support is believed to help beginning teachers (BTs) to cope with these first years of teaching and motivate them to stay in the profession (George, George, Gersten, \& Grosenick, 1995; Mansfield, Beltman, \& Price, 2014). In current research, collegial support is often measured in a rather generalised manner, using a single survey item or a composite Likert scale to reflect how teachers generally perceive collegial support (e.g. items such as 'My colleagues assist me in acquiring the knowledge, skills, and strategies to be successful in the classroom' (cf. Stockard \& Lehman, 2004)). Recently, however, several scholars have argued the need to understand collegial support in a more comprehensive way (e.g. Borman \& Dowling, 2008), for example, by taking a social network perspective (Baker-Doyle, 2010). 
Research taking a social network perspective on collegial support conceptualises support as a resource that is embedded in the web of relationships between the BT and his/her colleagues (Borgatti, Brass, \& Halgin, 2014). Such a perspective facilitates a more fine-grained approach to studying collegial support (Coburn, Russell, Kaufman, \& Stein, 2012), for example, by examining the teachers' support relationships with colleagues, in terms of the frequency, usefulness and range of these relationships (e.g. Author et al., 2015).

Several scholars have drawn on a social network perspective in the context of educational change (Daly, 2010), leadership (Pitts \& Spillane, 2009) and curriculum implementation (Coburn et al., 2012). Yet, in research on teacher induction, understanding of BTs' social networks is limited. Taking a social network perspective is likely to yield a more comprehensive understanding of the relationships through which BTs may (or may not) receive collegial support. Moreover, this perspective offers insight into the extent to which characteristics of collegial support networks (e.g. frequency and usefulness) are related to key factors affecting teacher retention, such as job satisfaction, motivation to teach, and self-efficacy. A more detailed understanding on the relationships through which collegial support may (or may not) flow, instead of teachers' (generalised) perceptions of collegial support, will provide valuable insight into levers to strengthen BTs' support networks (Author et al., 2018), thereby adding to the existing research on teachers' first years in the profession.

\section{Theoretical framework}

\section{The teacher induction period}

The teacher induction period refers to the transition from teacher education to the teaching profession, and comprises the first years in practice (Huling-Austin, Odell, Ishler, Kay, \& 
Edelfelt, 1989). In this transitional period, professional development is particularly intense (Feiman-Nemser, 2001) and BTs are confronted with numerous challenges (Tickle, 2000; Veenman, 1984), leading to what has been referred to as 'an emotional rollercoaster' (Mansfield et al., 2014). BTs not only expand their professional knowledge, skills and abilities, but also develop their self-image as a teacher and adjust to the school's culture and climate (FeimanNemser, 2001; Kessels, 2010).

BTs are often expected to take on the same responsibilities and duties as their more experienced colleagues (Tynjälä \& Heikkinen, 2011), yet they are seldom afforded the opportunity to evolve into the job (Kessels, 2010). Unlike veteran teachers, their experience is limited and in some situations may prove to be insufficient (Lidstone \& Ammon, 2002). Numerous scholars have reported difficulties that BTs encounter with issues such as classroom management, awareness of school policies, and heavy teaching load (see, e.g. the review study of Veenman, 1984, and first year teachers' stories in Rust, 1994). Inspired by earlier research (Vonk, 1995), Shoval, Erlich and Fejgin (2010) related BTs' difficulties to three aspects of teaching: (1) the professional aspect, i.e., transferring knowledge into practice; (2) the personal aspect, i.e., low self-confidence and anxiety; and (3) the environmental aspect, i.e., getting familiar with the school community.

BTs' awareness that they are not fully prepared for these responsibilities and difficulties often results in a praxis shock (Gold, 1996; Hebert \& Worthy, 2001), which can be defined as teachers' confrontation with the realities of the profession (Author et al., 2002). In reducing the praxis shock, research has increasingly recognised the strength of formal induction programmes (Fantilli \& McDougall, 2009; Tickle, 2000), such as mentoring by experienced teachers and professional development workshops and seminars (Stansbury \& Zimmerman, 2000). 
Despite the importance of formal induction programmes, Tickle (2000) argues that they do not automatically result in changes in BTs' learning environment, nor do they guarantee that BTs will fully exploit these opportunities. Therefore, next to formal induction programmes, informal collegial support is essential in teachers' first years in the profession (Papatraianou \& Le Cornu, 2014; Struyve et al., 2016), and should be a school-wide responsibility rather than limited to a few designated people (Feiman-Nemser, 2001; Hargreaves \& Fullan, 2000). As BTs' experiences in the induction period are believed to be critical for their further career (FeimanNemser, 2001), feeling supported by colleagues and tackling their negative experiences is of the utmost importance (Fantilli \& McDougall, 2009).

The significance of collegial support to BTs becomes even more pertinent in the context of the teacher retention crisis. The research literature highlights the global character of the retention crisis as well as efforts that are being made worldwide to tackle high rates of early attrition (Author et al., 2002; e.g. Burke et al., 2013; Borman \& Dowling, 2008). These studies point to the influence of fixed teacher and school characteristics (e.g. gender, ethnicity, class size, location), as well as alterable factors such as working conditions (e.g. workload, teacher pay, collegial support) (e.g. Borman \& Dowling, 2008; Newberry \& Allsop, 2017). Being provided with professional autonomy (Guarino, Santibanez, \& Daley, 2006; Ingersoll \& May, 2010), and at the same time being supported by colleagues (Burke et al., 2013; Geiger \& Pivovarova, 2018) are found to be particularly important to mitigating these conditions.

\section{Collegial support: an asset to retain BTs in the profession}

Relationships with colleagues are crucial (Daly, 2010; Le Cornu, 2013) for all teachers, but particularly for professional, emotional and environmental aspects of BTs' teaching (Shoval et al., 2012). Similarly, Snoeck et al. (2010) argue that in BTs' contact with their colleagues, three 
types of support are essential. First, professional support helps teachers to develop the required competences and grow professionally (Snoeck et al., 2010). This may include providing advice about didactics and teaching practices (Cole, 1991; Stansbury \& Zimmerman, 2000; Veenman, 1984). Second, emotional support helps BTs to overcome the praxis shock, and guide them through other personal difficulties (Snoeck et al., 2010; Stansbury \& Zimmerman, 2000). This may involve reducing emotional distress and encouraging self-confidence (Cole, 1991; Gold, 1996; Papatraianou \& Le Cornu, 2014). The importance of emotional support is illustrated by the high demands to constantly learn new teaching strategies (Hargreaves \& Fullan, 2000). Third, social support helps BTs to become part of the team and adjust to the school culture (Snoeck et al., 2010), such as including BTs into the team (Le Cornu, 2013) and informing them about school rules and procedures (Cole, 1991; Odell, 1986; Papatraianou \& Le Cornu, 2014).

\section{Taking a network perspective on collegial support}

In contrast with traditional approaches, in the social network perspective the unit of analysis is not the individual but rather the relationships between individuals (Borgatti, Brass, \& Halgin, 2014; Wellman, 1983). Here, support is not considered as an attribute of an individual, but as a potential resource that is embedded in the relationships ('ties') between people (Kilduff \& Tsai, 2003), conceptualised as social capital (Bourdieu, 1986). Applied to the current study's context, BTs are embedded in a web of support relationships through which they can receive professional, emotional and social support. As such, these relationships have the potential to fulfil cognitive needs for expertise, as well as affective needs for a sense of belonging (Fox \& Wilson, 2015). Furthermore, through BTs' relationships, that may be rich in (or deplete from) resources such as support, attitudes and behaviour concerning teacher retention may be confirmed or altered (Rippon \& Martin, 2006; E. Skaalvik \& S. Skaalvik, 2011). 
In this study, we focus on BTs' relationships with their colleagues as reflected in their ego-network. An ego-network is the set of relationships with alters (i.e. colleagues) that form around a particular ego (i.e. the BT) (Crossley et al., 2015, p. 18). Social network analysis (SNA) enables a fine-grained study of ego-networks and their characteristics (Borgatti, Everett, \& Johnson, 2013; Wellman, 1983). In the present study, three social network characteristics are explored to gain insight into BTs' support networks and how they are related to their inclination to stay in the profession, namely network size, frequency of support, and perceived usefulness. First, network size is defined as the number of colleagues from whom the BT receives support. Several studies have demonstrated that network size is important, as it reflects teachers' opportunities for accessing resources (Author et al., 2015; Struyve et al., 2016). Teachers with smaller support networks often feel isolated at school and are more prone to negative attitudes concerning their teaching career, which in turn may cause them to drop out (Anhorn, 2008; Cole, 1991). Second, frequency of support reflects the intensity of support received by BTs. Several studies on formal induction programmes have emphasised the importance of the quantity of the support, indicating that the more comprehensive and intensive the support, the higher its effectiveness (Ingersoll \& Strong, 2011). Third, perceived usefulness of support is regarded as a measure of the quality of support networks; the extent to which teachers perceive the support as helpful and valuable. Previous research has found that teacher retention is affected by the quality of the support BTs receive (Joiner \& Edwards, 2008).

Overall, using the social network perspective adds to the study in two ways. First, it provides the opportunity to expand the notion of 'collegial support' by focusing on support relationships in BTs' ego-network instead of a more generalised conceptualisation and measurement of collegial support. Second, a network perspective offers valuable measures and methods to access detailed information about BTs' support networks. As teachers' support 
networks can shape their attitudes and behaviour (Scott, Wasserman, \& Carrington, 2005), we argue that an increased understanding of characteristics of these support networks can contribute to our understanding of retaining teachers in the profession.

\section{Key factors for teacher retention in the teacher induction period}

The teacher induction period is described as both an emotional rollercoaster abundant in challenges and difficulties (Mansfield et al., 2014; Tickle, 2000) and an intensive period for the development of necessary skills (Feiman-Nemser, 2001). Reflecting this emotional and skills development of BTs, three key factors are often examined to assess whether BTs are inclined to stay in the profession, namely job satisfaction (Carmeli \& Weisberg, 2006), intrinsic motivation to teach (van den Broeck, Vansteenkiste, de Witte, Lens, \& Andriessen, 2009), and teachers' selfefficacy (Tschannen-Moran \& Woolfolk Hoy, 2001).

The first key factor, job satisfaction, is included in this study as it is often regarded as an emotional precursor of teacher retention (e.g. Carmeli \& Weisberg, 2006). Job satisfaction is conceptualised as teachers' affective responses to the amount of overlap between their expectations and the reality of teaching (Carmeli \& Weisberg, 2006). In this study, it is conceptualised as an overall sense of job satisfaction, rather than satisfaction with specific facets of the job (Skaalvik \& Skaalvik, 2011). Previous research has demonstrated the power of job satisfaction for BTs to survive and thrive in the first years of the profession (e.g. Carmeli \& Weisberg, 2006; Struyve et al., 2016). In line with previous research, this study examines whether BTs' (lack of) collegial support networks may affect their job satisfaction (Struyve et al., 2016), and, as such, ultimately affect their inclination to stay in the profession.

Similarly, the second key factor, BTs' intrinsic motivation to teach, is also regarded as an emotional precursor of retention. Intrinsic motivation to teach is defined as teachers fully 
endorsing the activity of teaching and teaching simply because they enjoy it (van den Broeck et al., 2009). In this study, intrinsic motivation to teach is seen as a conative component; intrinsic motivation is considered a combination of knowledge and affect that is then converted into action (Huitt, 1999). Translated into the context of BTs, this means that intrinsic motivation to teach entailing positive emotions and attitudes towards teaching (Canrinus, Helms-Lorenz, Beijaard, Buitink, \& Hofman, 2012) - encourages particular behaviour, namely less inclination to abandon the profession (Vansteenkiste et al., 2007). This definition of intrinsic motivation to teach shows that in the present study 'emotions' are conceptualised as having both a cognitive and affective dimension (Author et al., 2016a). In the self-determination theory (SDT) of Deci and Ryan (2000), intrinsic motivation to teach is seen as the most autonomous form of motivation. This theory argues that intrinsic motivation is achieved if three basic psychological needs are met: the need for competence (i.e. feeling effective), autonomy (i.e. the need to function without any external pressure), and the need for relatedness (i.e. feeling part of a coherent team). Along these lines, previous work suggested that teachers' intrinsic motivation to teach can be affected by levels of collegial support (Van den Broeck et al., 2009).

The third key factor, self-efficacy, refers to teachers feeling that they are capable of generating student learning and success (Bandura, 1997; Tschannen-Moran \& Woolfolk Hoy, 2001), thereby reflecting the skills development of BTs. In the present study, teachers' selfefficacy is defined as 'a judgement of one's capabilities to bring about desired outcomes of student engagement and learning' (Tschannen-Moran \& Woolfolk Hoy, 2001, p. 783). Several scholars have found that collegial support and teachers' self-efficacy are associated (Shachar \& Schmuelevitz, 1997; Mastenbroek et al., 2014). Moreover, previous studies have linked teachers' self-efficacy with their intention to leave, arguing that positive perceptions about their ability to 
be effective encourages teachers to stay in the profession (Hong, 2012; Wang, Hall, \& Rahimi, 2015).

\section{Purpose of the study}

The present study aims to investigate the relationship between collegial support networks and key factors affecting teacher retention using a social network perspective. First, in a descriptive phase, social network analysis is used to examine characteristics of BTs' professional, emotional and social support networks. Second, in an inferential phase, these social network characteristics are used to predict BTs' job satisfaction, intrinsic motivation to teach, and self-efficacy, as key factors that ultimately affect teacher retention. The study is framed around the following research question:

To what extent are the characteristics of BTs' professional, emotional and social support networks (i.e. network size, frequency of support, perceived usefulness) related to job satisfaction, intrinsic motivation to teach and self-efficacy, as key factors that ultimately affect teacher retention?

\section{Method}

\section{Sample and procedure}

In May 2016, all 19 teacher education colleges in Flanders that offered a degree in primary education were approached. Colleges that were willing to participate, were asked to forward an online survey to their graduate class of 2015. A total of 446 graduates responded, $89.5 \%$ being female. The average age of the sample was $24(s d=5)$. In total, 65\% ( $n=292)$ had entered the teaching profession whereas $7.6 \%$ had a non-teaching job. Twenty-two percent were pursuing an 
additional degree and $5.4 \%$ were unemployed.

An excerpt of the survey is provided in the appendix. The excerpt shows that in addition to biographical information (Part 1) and questions about their academic and career trajectory (Part 2), participants with a teaching job $(n=292)$ were asked about the key factors affecting teacher retention (Part 3) and the three types of support networks (Part 4). For the latter, an ego network approach was used (Crossley et al., 2015), focusing on the support relationships between the BT (ego) and his/her colleagues (alters). This ego network approach is suitable for gaining an in-depth understanding of ego's relationships and how this may be linked to other variables (Morrison, 2002), such as job satisfaction, intrinsic motivation to teach and self-efficacy.

In line with current social network research methods, network data were collected in two steps (Borgatti, et al., 2013; see Appendix: Part 4). First, a name generator was used, prompting an individual to list a number of people with whom they have a specific type of relationship (Crossley et al., 2015). In this study, BTs were asked: 'From which of your colleagues do you receive professional/emotional/social support?' In the survey, these three types of support were described based on the definitions of Snoeck et al. (2010). Additionally, we added short prompts to these questions to clarify what we meant by each type of support (see Appendix). For each type of support, participants could name up to 20 colleagues. Second, name interpreter questions were added to gain information on the nominated colleagues and the participant's relationship with them (Borgatti et al., 2013). Participants specified their colleagues' gender, educational experience, and the frequency (from 1='once every three months' to $5=$ 'daily') and perceived usefulness (from 1='never useful' to 5='always useful') of the professional, emotional and social support received. 


\section{Measures}

\section{Professional, emotional and social support}

To quantify teachers' support networks in social network characteristics, descriptive, preliminary social network analyses were conducted (Daly, 2010). Using the UCINET software (Borgatti, Everett, \& Freeman, 2002), two types of analyses were performed: alter analysis, and tie analysis (Borgatti et al., 2013; Crossley et al., 2015).

Alter analysis. To examine the support networks of BTs, we performed a detailed analysis of the BTs ('egos') and the colleagues from which they received support ('alters'). We calculated the measures of homogeneity (i.e. similarity among ego's alters), and homophily (i.e. similarity between ego and ego's alters) for gender and experience (see Borgatti et al., 2013). Gender homogeneity (i.e., the extent to which a BT's support network was dominated by a single gender) was assessed by Blau's heterogeneity index, which varies from 0 (homogeneity) to $1-(1 / \mathrm{r})$ (heterogeneity; with $\mathrm{r}$ as the number of categories, in this case 2, namely male/female) and its normalized version, the Index for Qualitative Variation (IQV), which varies from 0 (homogeneity) to 1 (heterogeneity). For experience, heterogeneity was measured by taking the standard deviation of the years of experience of alters in a BT's support network. Gender homophily was measured using the EI-index, ranging from +1 (heterophily) to -1 (homophily), which reflects the extent to which BT's colleagues have the same gender as the BT. For experience, homophily was calculated as the average (absolute) number of years between ego's and alters' years of educational experience.

Tie analysis. To examine the characteristics of BTs' support relationships, we took a closer look at the ties connecting the BTs to the alters from whom s/he indicated to receive support. Network size reflects the number of colleagues the participants nominated as offering 
support. For each BT, frequency of support was calculated as the average frequency of contact between the BT and his/her alters (from $1=$ 'once every three months' to $5=$ 'daily').

Correspondingly, perceived usefulness was calculated as the average reported usefulness of support, as rated by the BT for each of his/her alters (from $1=$ 'never useful' to $5=$ 'always useful'). It is important to note that two of the above network characteristics (i.e., frequency of support and perceived usefulness) are average measures at the ego level, whereby the variation within BTs (i.e. among ties) is not taken into account. To verify whether aggregation at the egolevel was acceptable, the Intra Class Correlation Coefficient (ICC) was computed (Shrout \& Fleiss, 1979). All ICCs were higher than .60, thereby justifying aggregation at the ego-level.

Job satisfaction, intrinsic motivation to teach and self-efficacy

Previously validated instruments were used to measure job satisfaction (Caprara, Barbaranelli, Steca \& Malone, 2003), intrinsic motivation to teach (Soenens, Sierens, Vansteenkiste, Dochy, \& Goossens, 2012), and self-efficacy (Tschannen-Moran \& Woolfolk Hoy, 2001). The validity and reliability of these scales for the present data set was reaffirmed using Confirmatory factor analyses (CFA) and Cronbach's Alphas. For CFA, several fit indicators were used: the Comparative Fit Index (CFI), the Tucker-Lewis Index (TLI), the Root Mean Squared Error of Approximation (RMSEA), the Standardised Root Mean Square Residual (SRMR), and the $\chi^{2}$ test. For the CFI and TLI, a critical value of .90 is put forward for a reasonable fit, and a fit larger than .95 is good (Hu \& Bentler, 1999). For the RMSEA and SRMR, a fit between .06 and .08 is reasonable, and a fit below .06 is good (Hu \& Bentler, 1999). In case of a non-significant $\chi 2$ test (p>.05), the model fit is assessed as good (Hu \& Bentler, 1999). However, as the $\chi^{2}$ test is sensitive to sample size, it is usually significant with large sample sizes (Muthén \& Muthén, 2015). Therefore, for every instrument, the $\chi^{2} / \mathrm{df}$ ratio was checked. A value of $\leq 2$ demonstrates 
a good fit, and a value of $\leq 3$ is considered acceptable (Schermelleh-Engel, Moosbrugger, \& Müller, 2003). Table 1 provides an overview of these validated instruments, including example items, range, number of items, fit indicators, and Cronbach's alpha.

\section{[Table 1]}

\section{Analyses}

For the descriptive phase of the study, concerning the investigation of BTs' support networks, a series of social network characteristics were calculated using social network analysis (see alter and tie analysis in Measures).

For the inferential phase of the study, namely the exploration of the extent to which characteristics of BTs' support networks are related to key factors affecting teacher retention, regression analyses were conducted using SPSS Statistics 22. In these regressions, three social network characteristics (i.e. network size, average frequency of support, and average perceived usefulness) were included as independent variables, and job satisfaction, intrinsic motivation to teach, and self-efficacy were used as the dependent variables. A separate regression model was fitted for every type of support network (professional, emotional and social support) on every dependent variable. To fit these models, the procedure of Chatterjee, Hadi, and Price (2000) was used. First, every independent variable was examined and assessed by means of univariate analysis. In this first explorative step, a significance level (p-value) of .20 was used as a criterion. All variables with a p-value of .20 or smaller were included in the full linear regression model. Second, the full linear regression model was fitted. In this second step, a stricter criterion was applied. More specifically, the variables with a p-value of .05 or higher were eliminated and 
excluded from further analysis. Third, the reduced model was fitted, for which the necessary assumptions were checked. Figure 1 visualises the scope of the study.

\section{[Figure 1]}

\section{Results}

\section{Descriptives}

On average, between their graduation (June 2015) and the moment they filled out the questionnaire (May 2016) the BTs in our sample $(n=292)$ had worked in three different primary schools ( $s d=2.81)$. Most of them were working full-time at one school $(n=203)$ and were uncertain about future work opportunities. Only $20 \%$ were sure of a contract at the same or another school in the near future.

Results of the independent variables and other social network characteristics (the descriptive phase of the study) are depicted in Table 2. This table shows that BTs receive professional, emotional and social support from, on average, six colleagues, and on a weekly basis. The support is assessed as 'useful most of the time.' Support to both female and male BTs is mainly offered by female colleagues (gender homogeneity), reflected in the IQV. In addition, results suggest homophily for female BTs (i.e. they receive support from people of the same sex), and heterophily for male BTs (i.e. they receive support from people of the opposite sex), as reflected in the EI-indexes. Finally, BTs mostly receive professional, emotional and social support from more experienced colleagues, as reflected in the average difference in experience between the BT and his/her alters of about 16 years. In addition, the standard deviation of alters' experience, which is an indicator of the similarity among ego's alters, is around 6 years.

[Table 2] 
The descriptives of the dependent variables are displayed in Table 3. The results show that BTs experience high levels of job satisfaction and intrinsic motivation to teach, and moderate to high levels of self-efficacy.

\section{[Table 3]}

\section{Regression analyses}

To answer the central research question (the inferential phase of the study), regression analyses were performed between the independent variables and the key factors affecting teacher retention.

Following the procedure of Chatterjee et al. (2000), every dependent variable (i.e. job satisfaction, intrinsic motivation to teach, self-efficacy) was assessed univariately (step 1) before a full linear regression model was fitted (step 2).

For the univariate regressions of both emotional and social support on job satisfaction, the three independent variables had a p-value of .20 or smaller. In the second step, however, the relationships with frequency of emotional $(B=.04, S E=.04, \beta=.07, p=.288)$ and social support $(B=.07, S E=.04, \beta=.13, p=.062)$ did not appear to be significant at a .05 significance level. For the univariate regressions of professional support on job satisfaction, both network size and perceived usefulness of support were statistically significant on the .20 level (step 1) and .05 level (step 2). In contrast, frequency of support was already eliminated after the first step, because of its non-significant relationship to job satisfaction at the .20 significance level $(B=.05, S E=.04$, $\beta=.07, p=.232)$.

For the regressions of professional, emotional and social support on intrinsic motivation to teach, in all cases, the three independent variables 'network size', 'frequency of support' and 'perceived usefulness' had a p-value of .20 or smaller. However, in the second step the 
relationship with the independent variable 'frequency of support' was not significant at a .05 significance level for professional support $(B=.04, S E=.04, \beta=.06, p=.330)$, emotional support $(B=.02, \mathrm{SE}=.04, \beta=.04 ; p=.600)$, and social support $(B=.03, S E=.04, \beta=.07, p=.339)$.

Finally, for self-efficacy, the regressions of the independent variables concerning emotional, and social support were not significant in the first step. Consequently, the full linear regression model could not be fitted. For professional support, the relationship with one independent variable, in particular 'perceived usefulness,' was statistically significant in the first $\operatorname{step}(B=.14, S E=.05, \beta=.18, p=.004)$.

In a third step, only those variables that were significant at the .05 level in the second step were included in the final reduced models. The statistics of these models are presented in Table 4.

\section{[Table 4]}

As Table 4 shows, in the final reduced models the relationships between network size and job satisfaction were statistically significant for professional $(B=.04, S E=.01, \beta=.24, p=.000)$, emotional $(B=.03, S E=.01, \beta=.20, p=.002)$, and social support $(B=.03, S E=.01, \beta=.21, p=.001)$. The same applies for the relationships between perceived usefulness and job satisfaction, in the case of professional $(B=.28, S E=.06, \beta=.27, p=.000)$, emotional $(B=.15, S E=.05, \beta=.19, p=.003)$ and social support $(B=.20, S E=.05, \beta=.25, p=.000)$.

For intrinsic motivation to teach, the relationship with network size was statistically significant for professional $(B=.03, S E=.01, \beta=.17, p=.005)$, emotional $(B=.03, S E=.01, \beta=.18$, $p=.004)$ and social support $(B=.02, S E=.01, \beta=.15, p=.016)$. The relationship between perceived usefulness and intrinsic motivation to teach was also statistically significant with respect to professional $(B=.25, S E=.06, \beta=.24, p=.000)$, emotional $(B=.17, S E=.05, \beta=.23, p=.000)$ and $\operatorname{social}(B=.21, S E=.05, \beta=.27, p=.000)$ support. 
As far as job satisfaction is concerned, network size and perceived usefulness together accounted for respectively $13.5 \%$ of the variance for professional support, $8.4 \%$ for emotional support and $12.5 \%$ for social support. For intrinsic motivation to teach, they accounted for $8.9 \%$ for professional support, $9.5 \%$ for emotional support, and $11 \%$ for social support. As already shown above, for self-efficacy only one statistically significant relationship was found, perceived usefulness of professional support $(B=.14, S E=.05, \beta=.18, p=.004)$, and only accounted for $3 \%$ of the variance.

The results concerning the partial eta squared (i.e. the proportion of variance explained by one variable and no other variables in the analysis) revealed that perceived usefulness most often had a stronger relationship with the predicted outcomes than network size. For instance, for professional support networks, the predicted effect of perceived usefulness on intrinsic motivation to teach is twice as strong as network size $\left(\eta_{p}^{2}=.060\right.$ vs. $\left.\eta_{p}{ }^{2}=.031\right)$. For social support networks, the predicted effect of perceived usefulness on intrinsic motivation to teach is even three times stronger than network size $\left(\eta_{p}{ }^{2}=.072\right.$ vs. $\left.\eta_{p}{ }^{2}=.024\right)$.

\section{Discussion}

This study examined the importance of collegial support for BTs during the induction period of their teaching career and the likelihood of this retaining them in the profession. This study adds to the existing body of research on collegial support (e.g. George et al., 1995; Stockard \& Lehman, 2004) by addressing support from a network perspective, focusing on specific characteristics of BTs's support networks.

To our knowledge, this study is the first to apply this network perspective to three vital types of support (i.e. professional, emotional, and social) present in the teacher induction period 
(Snoeck et al., 2010). Furthermore, rather than investigating BTs' retention directly, we consider well-documented factors affecting teacher retention. Inspired by the literature on teacher induction, we have considered job satisfaction and intrinsic motivation to teach as emotional precursors of teacher retention, and teachers' self-efficacy as a skills-related precursor. This enabled us to examine the potential of support from colleagues to fulfil both cognitive and affective needs (Fox \& Wilson, 2015).

\section{BTs' collegial support from a network perspective}

The descriptive, preliminary social network analyses have enabled a fine-grained investigation of collegial support by focusing on several social network characteristics (Borgatti et al. 2013). The results show that BTs receive each type of support from on average six colleagues. Based on a recent report of the Flemish Department of Education and Training (2016), an average primary school team consists of 18 people. This suggests that BTs receive professional, emotional and social support from on average one third of their team. The support is usually regarded as useful. Moreover, most team members who offer support do so on a weekly basis, as was previously indicated by Author et al. (2016c). To our knowledge, however, research on the frequency of collegial support is scarce and more is required to further interpret this result.

Our social network analysis further reveals that participants tend to receive the most support from female colleagues. This is to be expected as the workforce in primary schools in many Western countries, including Belgium, is largely female (Cushman, 2010; Flemish Department of Education and Training, 2016). It also implies that female BTs will mainly receive homophilious support, and male BTs will mostly consult female teachers.

With regard to the concept of homophily, it is noteworthy that the data for this study were collected via an ego network design (Borgatti et al., 2013). As a result, there is only information 
on people who were named as support givers by the BTs. Because there is no information on other people at the schools, it is impossible to determine whether homophily can be attributed to mere availability (i.e. female teachers receive support from female colleagues because there are few male colleagues in their school network) or actual preference (i.e. female teachers choose to interact more with female colleagues).

Another important finding based on the descriptive, preliminary social network analysis is that BTs mostly tend to receive support from experienced colleagues. As BTs are often expected to take on the same responsibilities as experienced teachers (Tynjälä \& Heikkinen, 2011), this kind of support is vital, since it gives them access to the knowledge and skills needed to survive the daily teaching practice (Fox \& Wilson, 2015).

\section{The relation between collegial support networks and key factors affecting teacher retention}

High-quality support as a resource for job satisfaction and intrinsic motivation to teach

The first finding from the explorative analyses reveals that network size is related to both job satisfaction and intrinsic motivation to teach. This suggests that the more colleagues offer support, the higher BTs' job satisfaction and intrinsic motivation to teach will be. This is in line with the study of Struyve et al. (2016), in which BTs' social connectedness with colleagues showed a positive relation with teacher retention, via increased positive emotional attitudes such as job satisfaction. It also aligns with the study from Author et al. (2015) in which they concluded that teachers' network size is important, as receiving input from a diverse number of colleagues results in rich resources, supporting further teacher development. Moreover, our result confirms previous studies stressing the importance of support from colleagues in this respect (e.g. 
Cole,1991; Kelley, 2004), and endorses the notion that support for BTs should be considered a school-wide responsibility (Feiman-Nemser, 2001).

Secondly, by using the social network analysis, a more nuanced picture of the importance of collegial support is obtained, because of the investigation of both frequency and perceived usefulness of support. Interestingly, the frequency of professional, emotional and social support are not found to be significantly related to job satisfaction, intrinsic motivation to teach, or selfefficacy. In contrast, the quality of these three types of support (i.e. perceived usefulness) was significantly related to job satisfaction as well as intrinsic motivation to teach. This seems to indicate that the more useful the professional, emotional and social support from their colleagues is, the more BTs are satisfied with their jobs and intrinsically motivated to teach. This is in line with Joiner and Edwards (2008) who found that the quality of the support for BTs influences their intentions to stay in or leave the profession. Thus, it could be assumed that when BTs receive these types of support, they do not necessarily feel supported: collegial relationships are ties that have the potential (Author, 2010) to enhance these emotional precursors of teacher retention, but quality takes precedence over quantity. In short, we may hypothesise that BTs need to receive useful support to actually feel supported. In terms of what exactly constitutes 'useful' support, Stansbury and Zimmerman (2000) emphasise that colleagues should serve as a sounding board for BTs and Gaikhorst et al. (2014) emphasise that BTs feel supported if they are listened to and feel appreciated.

Thirdly, on a descriptive basis, we observed small differences in the various types of support: professional and social support seem to account more for the variance in job satisfaction than emotional support. For intrinsic motivation to teach, social support has the highest explained variance and professional support the lowest. However, these differences are rather small, and more detailed analyses should be conducted to explore this thoroughly. 
Furthermore, it is interesting that next to emotional and social support, professional support also appears to be positively related with the emotional precursors. This may indicate that supporting teachers professionally makes them more content with their job and gives them more intrinsic motivation to teach.

The finding that professional support is positively related to job satisfaction may be explained through the definition of job satisfaction. Particularly, job satisfaction is defined as a reaction to the extent to which teachers' expectations correspond with reality (Carmeli \& Weisberg, 2006). In a highly connected team, BTs are supported in their daily teaching and are given advice on instructional and didactical strategies as well as class management. This support in their professional development could thus enable them to better cope with the praxis shock (Author et al., 2002) and consequently create more overlap between their expectations and reality.

For intrinsic motivation to teach, the positive relation with professional support could be explained by SDT: in order for someone to be intrinsically motivated to teach, their basic psychological needs should be met (Deci \& Ryan, 2000; Soenens et al., 2012). If professional support is provided, one of those needs could be fulfilled (particularly the need for competence) and teachers' intrinsic motivation to teach may be boosted.

Collegial support, however, has an impact on both teachers' competences and their sense of relatedness (Author et al., 2016a). In this respect, SDT could also be used to explain the positive relation between intrinsic motivation to teach, and emotional and social support. If teachers get emotional and social support, their need for relatedness (i.e. feeling part of a coherent team in which personal feelings and thoughts can be shared) could be fulfilled, which in turn may enhance their intrinsic motivation to teach (Deci \& Ryan, 2000; Gagné \& Deci, 2005; Skaalvik \& Skaalvik, 2011). 
Moreover, according to SDT, the positive impact of collegial support on intrinsic motivation to teach is especially prominent if it strengthens teachers' need for autonomy rather than creating permanent dependency (Deci \& Ryan, 2000). This pertains to the idea that collegial support and teacher autonomy are mutually interdependent and should operate in a healthy balance (Toole \& Louis, 2002). Enjoying a supportive network while having autonomy is pivotal to keeping teachers in the profession (Ingersoll \& May, 2010).

In sum, and consistent with the research of Snoeck et al. (2010), the present study stresses the importance of all three types of support to encourage a positive attitude and keep BTs in the profession.

The lack of a substantial relationship between collegial support networks and teachers' self-efficacy

Although network size and perceived usefulness of collegial support are positively related with the emotional precursors of teacher retention, the relation with self-efficacy as a skills-related precursor appears to be non-significant for emotional and social support.

For professional support, only perceived usefulness shows a statistically significant relationship. This is in line with Bandura's (1977) claim and Siciliano's (2016) evidence that convincing teachers of their own abilities and competences is not simply a matter of providing professional support but requires time, effort and enthusiasm from the support givers. Parallel to job satisfaction and intrinsic motivation to teach, the results seem to suggest that it is not the quantity but the quality of support that has the power to forge teachers' self-efficacy (Siciliano, 2016). Such qualitative professional support, according to Baker-Doyle (2012), should be continuous and authentic, promoting a critical attitude in BTs by encouraging them to reflect on 
their practice. However, the explained variance is rather limited, suggesting that the perceived usefulness of professional support is a small predictor of self-efficacy.

The lack of a substantial positive relation between professional support and self-efficacy contradicts empirical evidence from previous studies, in which opportunities for professional development, such as professional collegial support, were found to be positively related to selfefficacy (Mastenbroek et al., 2014).

A statistical explanation for our conflicting results could be the small amount of variation in self-efficacy. A theoretical explanation could be the limited experience of the teachers in our sample; Chan, Lau, Nie, Lim, and Hogan (2008) found a positive relation between years of experience and self-efficacy. Related to this, Bandura (1997) states that self-efficacy increases through 'mastery experiences,' which can be described as 'a sense of satisfaction with one's past teaching successes ... which for teachers come[s] from actual teaching accomplishments with students' (Tschannen-Moran \& Woolfolk Hoy, 2007, p. 945). In this respect, it could be hypothesised that BTs' self-efficacy might remain unchanged even upon receiving professional support, if the support received does not result in successful teaching experiences. These 'mastery experiences' might therefore be a mediator in the relationship between professional support and self-efficacy. Furthermore, based on earlier research (Chester \& Beaudin, 1996; TschannenMoran \& Woolfolk Hoy, 2007), it could be argued that these experiences of success are created by providing opportunities for BTs to collaborate closely with experienced colleagues and receive feedback after classroom observations.

\section{Limitations, recommendations for further research and implications}

Several limitations should be acknowledged. First, our sample is somewhat biased, as participation in the study was voluntary. It is likely that the high scores for both the independent 
variables and factors affecting teacher retention are caused by the eagerness of BTs with a positive story to participate.

Secondly, although the independent variables capture the number of support givers and the frequency and perceived usefulness of support, the actual nature of these collegial support networks was not studied. Future research could tackle this issue with a mixed-method design study, in which quantitative findings are refined with qualitative interpretations. Moreover, by focusing on characteristics of BTs' ego support networks, we have taken a first step in applying a relational perspective to collegial support. In further studies, more advanced quantitative social network analyses or a whole network approach - taking into account the entire school network and the position of the BT in said school network - could be implemented.

Third, the explained variance in job satisfaction, intrinsic motivation to teach and selfefficacy was rather small. When interpreting these results, we need to keep in mind that many other aspects (e.g. school culture, teachers' personality) may also influence these factors affecting teacher retention.

Fourth, the type of teachers' preparation programme was not included as a control variable. The present study focuses on primary school teachers. However, in Flanders there is only one available primary school teacher programme (i.e. a three-year professional bachelor's programme offered by institutes of higher education). Secondary teachers have several possibilities: a three-year professional bachelor's programme at an institute of higher education, a one-year subject-specific academic teacher training at a university, or a teacher training at an adult education centre. Further research could explore the extent to which the education level of the teacher, and/or the type of institution influence the studied relationships. Furthermore, variables related to the content and quality of teacher education programmes could also be considered in the context of teacher induction. Several researchers have established a link 
between teacher retention, and initial teacher education (e.g., Ruhland, 2001). In this respect, further research could examine variables to measure teachers' feelings of being adequately prepared for the profession, as well as their perception of the quality of the support and supervision during their initial training (see, Rots \& Aelterman, 2009).

The fifth limitation concerns the descriptive nature of the investigation of the differences between types of collegial support networks. To discuss this in depth, more advanced analyses are needed. Further research could, for example, conduct path analyses for all types of collegial support networks and compare their pathways.

As a sixth and final limitation, we want to emphasise that, due to the explorative nature of this study, the results should be interpreted with caution. Further research is necessary to investigate the relationships under study more in depth. Furthermore, due to the specificity of the Flemish induction policy, the study's findings cannot be easily generalised to other contexts. After a decree granting schools additional funding for 'mentoring hours' was revoked in 2010, schools again became the main responsible for supporting their BTs (Author et al., 2013; Author et al., 2016b). Nowadays, they are not obliged to spend part of their budget on mentoring, and formal initiatives are rare. As a result, BTs largely rely on informal support from colleagues. While the situation may be similar in other countries, it would nevertheless be interesting to explore whether these circumstances have affected our results; further research in other contexts is therefore warranted.

Despite these limitations, the study's findings allude to the power of high-quality support in teacher induction, and may equip practitioners and policy-makers with concrete suggestions concerning how to retain BTs. More specifically, the results indicate that high-quality support is important for both job satisfaction and intrinsic motivation to teach, implying that time and space should be created for teachers to support each other. Our findings seem to emphasise the shared 
responsibility of the entire school team (Feiman-Nemser, 2001), where high-quality support should be organised for BTs. Furthermore, both professional and emotional and social support emerge as important factors. In line with these results, we suggest that aside from support with pedagogical and didactical competences (i.e. professional support), BTs should also receive support to deal with their emotions and stress (i.e. emotional support) and become part of the school team (i.e. social support) (Hargreaves \& Fullan, 2000; Author et al., 2016a). Finally, our findings suggest that professional support alone is inadequate to change BTs' self-efficacy. Following Bandura (1997), such support may only result in increased self-efficacy if the individual also experiences success. In this respect, we hypothesise that more intense collaboration among teachers, long-term and close follow-up, and maybe even co-teaching could increase experiences of success.

\section{Conclusion}

Worldwide, many teachers leave the profession during their first years in practice. Previous studies underlined the importance of collegial support to keep BTs in the profession. However, few studies in the context of the induction period have offered insights in collegial support in a comprehensive way. The present study therefore investigated collegial support using a social network perspective. More particularly, in a first descriptive phase using social network analysis, key characteristics of BTs' professional, emotional and social collegial support (i.e. network size, frequency of support, perceived usefulness) were examined. In a second inferential phase, these social network characteristics were used to predict BT's job satisfaction, intrinsic motivation to teach and self-efficacy, as key factors affecting teacher retention.

The findings from this study suggest that high-quality collegial support for BTs is crucial for their job satisfaction and intrinsic motivation to teach. Moreover, not only professional, but 
also emotional and social support are important. BTs want to feel supported and want to feel part of the team. Building on the often-cited metaphor of the induction period as a time of 'sink or swim' (Feiman-Nemser, 2001, p. 1014), these results demonstrate the power of swimming together, rather than sinking alone. But how can we promote teachers to swim together? How can we promote the induction of BTs as a school-wide responsibility? School principals could play an important role, by encouraging the team to be accessible for and willing to offer support to BTs. Additionally, BTs could be made more aware of the connections they can forge in the team, and whom they can access for help with specific issues that they are struggling with. A promising road for increasing awareness regarding the 'hidden' potential of teachers' support networks is visualizing teachers' networks using network maps (Schreurs \& de Laat, 2014). Moreover, teacher education too could be a powerful force in increasing teachers' network awareness, by emphasising the importance of collegial support in navigating the unknowns of the challenges ahead, as well as by stimulating the development of networking skills.

In sum, this study highlights the power of high-quality collegial support networks for beginning teachers' first years in the profession, and the added value of exploring collegial support in a network-focused way. We believe that further unravelling the social side of the teacher induction period can lead us to valuable input for both practice and policy, with the ultimate aim of supporting BTs, their colleagues, and the children they teach. 


\section{References}

Author (1993). Details removed for review.

Author et al. (2002). Details removed for review.

Author (2010). Details removed for review.

Author et al. (2013). Details removed for review.

Author et al. (2015). Details removed for review.

Author et al. (2016a). Details removed for review.

Author et al. (2016b). Details removed for review.

Author et al. (2016c). Details removed for review.

Author et al. (2016d). Details removed for review.

Author et al. (2018). Details removed for review.

Anhorn, R. (2008). The profession that eats its young. Delta Kappa Gamma Bulletin, 74, 15-

26.

Baker-Doyle, K.J. (2010). Beyond the labor market paradigm: A social network perspective on teacher recruitment and retention. Education Policy Analysis Archives, 18(26). doi: 10.14507/epaa.v18n26.2010

Baker-Doyle, K.J. (2012). First-year teachers’support networks: Intentional professional networks and diverse professional allies. The New Educator, 8, 65-85. doi: 10.1080/1547688X.2012.641870

Bandura, A. (1977). Self-efficacy: Toward a unifying theory of behavioral change. Psychological Review, 84, 191-215. doi: 10.1037/0033-295X.84.2.191

Bandura, A. (1997). Self-efficacy: The exercise of control. New York, NY: W.H. Freeman.

Borgatti, S.P., Brass, D.J., \& Halgin, D.S. (2014). Social network research: Confusions, criticisms, and controversies. In D.J. Brass, G. Labianca, A. Mehra, D.S. Halgin, \& S.P. 
Borgatti (Eds.), Research in Sociology of Organizations Series, (40, pp. 1-32).

Bradford: Emerald.

Borgatti, S.P., Everett, M.G., \& Freeman, L.C. (2002). Ucinet 6 for Windows: Software for Social Network Analysis. Harvard, MA: Analytic Technologies.

Borgatti, S.P., Everett, M.G., \& Johnson, J.C. (2013). Analyzing social networks. London: Sage.

Borman, G.D., \& Dowling, N.M. (2008). Teacher attrition and retention: A meta-analytic and narrative review of the research. Review of Educational Research, 78, 367-409. doi: $10.3102 / 0034654308321455$

Bourdieu, P. (1986). The forms of capital. In J. Richardson (Ed.), Handbook of Theory and Research for the Sociology of Education (pp. 241-258). New York, NY: Greenwood.

Burke, P.F., Schuck, S., Aubusson, P., Buchanan, J., Louviere, J.J., \& Prescott, A. (2013). Why do early career teachers choose to remain in the profession? The use of best-worst scaling to quantify key factors. International Journal of Educational Research, 62, 259-268. doi: 10.1016/j.ijer.2013.05.001

Canrinus, E.T., Helms-Lorenz, M., Beijaard, D., Buitink, J., \& Hofman, A. (2012). Self-efficacy, job satisfaction, motivation and commitment: Exploring the relationships between indicators of teachers' professional identity. European Journal of Psychology of Education, 27, 115-132. doi: 10.1007/s10212-011-0069-2

Caprara, G.V., Barbaranelli, C., Borgogni, L., \& Steca, P. (2003). Efficacy beliefs as determinants of teachers' job satisfaction. Journal of Educational Psychology, 95, 821832. doi: 10.1037/0022-0663.95.4.821 
Carmeli, A., \& Weisberg, J. (2006). Exploring turnover intentions among three professional groups of employees. Human Resource Development International, 9, 191-206. doi: $10.1080 / 13678860600616305$

Chan, W.-Y., Lau, S., Nie, Y., Lim, S., \& Hogan, D. (2008). Organizational and personal predictors of teacher commitment: The mediating role of teacher efficacy and identification with school. American Educational Research Journal, 45, 597-630. doi: $10.3102 / 0002831208318259$

Chatterjee, S., Hadi, A.S., \& Price, B. (2000). Regression Analysis by Example (3th ed.). New York, NY: John Wiley \& Sons.

Chester, M.D., \& Beaudin, B.Q. (1996). Efficacy beliefs of newly hired teachers in urban schools. American Educational Research Journal, 33, 233-257. doi: 10.3102/00028312033001233

Coburn, C., Russell, J.L., Kaufman, J.H., \& Stein, M.K. (2012). Supporting sustainability: Teachers advice networks and ambitious instructional reform. American Journal of Education, 119(1), 137-182. doi: 10.1086/667699

Cole, A. L. (1991). Relationships in the workplace: Doing what comes naturally? Teaching \& Teacher Education, 7, 415-426. doi: 10.1016/0742-051X(91)90038-Q

Cooper, J.M., \& Alvarado, A. (2006). Preparation, recruitment, and retention of teachers: Education Policy Series. Paris: UNESCO.

Crossley, N., Bellotti, E., Edwards, G., Everett, M., Koskinen, J., \& Tranmer, M. (2015). Social network analysis for ego-nets. London: SAGE.

Cushman, P. (2010). Male primary school teachers: Helping or hindering a move to gender equity? 
Teaching and Teacher Education, 26, 1211-1218. doi: 10.1016/j.tate.2010.01.002

Daly, A. (Ed.). (2010). Social network theory and educational change. Cambridge, MA: Harvard Education Press.

Day, C. (1999). Developing teachers: the challenge of lifelong learning. London: Falmer Press.

Deci, E.L., \& Ryan, R.M. (2000). The "what" and "why" of goal pursuits: Human needs and the self-determination of behaviour. Psychological Inquiry, 11, 227-268. doi: 10.1207/S15327965PLI1 104_01

Fantilli, R.D., \& McDougall, D. E. (2009). A study of novice teachers: Challenges and supports in the first years. Teaching and Teacher Education, 25(6), 814-825. doi: $10.1016 / j . t a t e .2009 .02 .021$

Feiman-Nemser, S. (2001). From preparation to practice: Designing a continuum to strengthen and sustain teaching. Teachers College Record, 103, 1013-1055. doi: 10.1111/0161-4681.00141

Flemish Department of Education and Training (2013). Arbeidsmarktrapport prognose 2011-2015. Basisonderwijs en Secundair Onderwijs [Labour market prognosis 2011-2015. Elementary and secondary education]. Brussels: Author.

Flemish Department of Education and Training (2016). Vlaams onderwijs in cijfers. Schooljaar 2015-2016 [Flemish education in numbers. Schoolyear 2015-2016]. Brussels: Author.

Fox, A., \& Wilson, E. (2015). Networking and the development of professionals: Beginning teachers building social capital. Teaching and Teacher Education, 47, 93-107. doi: 10.1016/j.tate.2014.12.004

Gagné, M., \& Deci, E. L. (2005). Self-determination theory and work motivation. Journal of 
Organizational Behaviour, 26, 331-362. doi: 10.1002/job.322

Gaikhorst, L., Beishuizen, J.J., Korstjens, I.M., \& Volman, M.L.L. (2014). Induction of beginning teachers in urban environments: An exploration of the support structure and culture for beginning teachers at primary schools needed to improve retention of primary school teachers. Teaching and Teacher Education, 42, 23-33. doi: 10.1016/j.tate.2014.04.006

Geiger, T., \& Pivovarova, M. (2018). The effects of working conditions on teacher retention. Teachers and Teaching, 602, 1-22. doi: 10.1080/13540602.2018.1457524

George, N. L., George, M. P., Gersten, R., \& Grosenick, J. K. (1995). To leave or to stay? An exploratory study of teachers of students with emotional and behavioral disorders. Remedial and Special Education, 16(4), 227-236. doi: 10.1177/074193259501600406

Gold, Y. (1996). Beginning teacher support: Attrition, mentoring, and induction. In J. Sikula, T. J. Buttery, \& E. Guyton (Eds.), Handbook of research on teacher education (2 ${ }^{\text {nd }}$ ed., pp. 548594). New York, NY: Macmillian.

Guarino, C.M., Santibanez, L., \& Daley, G.A. (2006). Teacher Recruitment and Retention: A Review of the Recent Empirical Literature. Review of Educational Research, 76(2), 173-208. doi: $10.3102 / 00346543076002173$

Hargreaves, A., \& Fullan, M. (2000). Mentoring in the new millenium. Theory into Practice, 39, 50-56. doi: 10.1146/annurev.polisci.11.060606.135342

Hebert, E., \& Worthy, T. (2001). Does the first year of teaching have to be a bad one? A case study of success. Teaching and Teacher Education, 17(8), 897-911. doi: 10.1016/S0742051X(01)00039-7 
Hong, J.Y. (2012). Why do some beginning teachers leave the school, and others stay? Understanding teacher resilience through psychological lenses. Teachers and Teaching: Theory and Practice, 18(4), 417-440. doi: 10.1080/13540602.2012.696044

Hu, L.-t., \& Bentler, P.M. (1999). Cutoff criteria for fit indexes in covariance structure analysis: Conventional criteria versus new alternatives. Structural Equation Modeling: A multidisciplinary Journal, 6, 1-55. doi: :10.1080/10705519909540118

Huitt, W. (1999). Conation as an important factor of mind. Educational Psychology Interactive. Valdosta, GA: Valdosta State University. Retrieved from http://www.edpsycinteractive.org/topics/conation/conation.html

Huling-Austin, L., Odell, S., Ishler, P., Kay, R., \& Edelfelt, R. (1989). Assisting the beginning teacher. Reston, VA: Association of Teacher Educators.

Hunt, J.B., Darling-Hammond, L., Alvarado, A., Bryant, A.L., Castor, B., Chan, I.H., ... Al., E. (2003). No dream denied: A pledge to America's children. Washington, DC: National Commission on Teaching and America's Future.

Ingersoll, R.M. (2001). Teacher turnover and teacher shortages: An organizational analysis. American Educational Research Journal, 38, 499-534. doi: 10.3102/00028312038003499

Ingersoll, R.M., \& May, H. (2010). The magnitude, destinations, and determinants of mathematics and science teacher turnover. University of Pennsylvania, Philadelphia: Consortium for Policy Research in Education.

Ingersoll, R.M., \& Strong, M. (2011). The impact of induction and mentoring programs for beginning teachers: A critical review of the research. Review of Educational Research, 81, 201-233. doi: 10.3102/0034654311403323 
Joiner, S., \& Edwards, J. (2008). Novice teachers: Where are they going and why don't they stay? Journal of Cross-Disciplinary Perspectives in Education, 1(1), 36-43.

Kelley, L.M. (2004). Why induction matters. Journal of Teacher Education, 55, 438-448. doi: $10.1177 / 0022487104269653$

Kessels, C. (2010). The influence of induction programs on beginning teachers' well-being and professional development (Unpublished doctoral dissertation). Leiden University: The Netherlands.

Kilduff, M., \& Tsai, W. (2003). Social networks and organizations. London: Sage.

Le Cornu, R. (2013). Building early career teacher resilience: The role of relationships. Australian Journal of Teacher Education, 38(4), 1-16. doi: 10.14221/ajte.2013v38n4.4

Lidstone, M.-L., \& Ammon, P. (2002). A key to successful teaching is understanding and focusing on student learning: Implications for teacher development. ERS Spectrum, 20(4), 27-37.

Mansfield, C., Beltman, S., \& Price, A. (2014). “I'm coming back again!” The resilience process of early career teachers. Teachers and Teaching: Theory and Practice, 20, 547-567. doi: $10.1080 / 13540602.2014 .937958$

Mastenbroek, N.J.J.M., Jaarsma, A.D.C., Scherpbier, A.J.J.A., van Beukelen, P., \& Demerouti, E. (2014). The role of personal resources in explaining well-being and performance: A study among young veterinary professionals. European Journal of Work and Organizational Psychology, 23, 190-202. doi: 10.1080/1359432X.2012.728040

Morrison, E.W. (2002). Newcomers' relationships: The role of social network ties during socialization. Academy of Management Journal, 45(6), 1149-1160. 
Muthén, L.K., \& Muthén, B.O. (2015). Mplus User's Guide. Seventh Edition. Los Angeles, CA: Muthén \& Muthén.

Newberry, M., \& Allsop, Y. (2017). Teacher attrition in the USA: the relational elements in a Utah case study. Teachers and Teaching: Theory and Practice, 23(8), 863-880. doi: $10.1080 / 13540602.2017 .1358705$

Odell, S. J. (1986). Induction support of new teachers: A functional approach. Journal of Teacher Education, 37(1), 26-29. doi: 10.1177/002248718603700106

OECD. (2005). Teachers matter. Attracting, developing and retaining effective teachers. Paris: OECD.

Papatraianou, L. H., \& Le Cornu, R. (2014). Problematising the role of personal and professional relationships in early career teacher resilience. Australian Journal of Teacher Education, 39, 100-116. doi: 10.14221/ajte.2014v39n1.7

Pitts, V.V.M., \& Spillane, J.P.J. (2009). Using social network methods to study school leadership. International Journal of Research and Method in Education, 32(2), 185-207. doi: $10.1080 / 17437270902946660$

Rippon, J., \& Martin, M. (2006). Call me teacher: The quest of new teachers. Teachers and Teaching: Theory and Practice, 12, 305-324. doi: 10.1080/13450600500467605

Rots, I., \& Aelterman, A. (2009). Teacher education graduates' entrance into the teaching profession: Development and test of a model. European Journal of Psychology of Education, 24, 453-471.

Ruhland, S.K. (2001). Factors that influence the turnover and retention of Minnesota's technical 
college teachers. Journal of Vocational Education Research, 26, 56-76. doi:

10.5328/JVER26.1.56

Rust, F.O'.C. (1994). The first year of teaching: It's not what they expected. Teaching and Teacher Education, 10, 205-217.

Schermelleh-Engel, K., Moosbrugger, H., \& Müller, H. (2003). Evaluating the fit of structural equation models: Tests of significance and descriptive goodness-of-fit measures. Methods of Psychological Research Online, 8(2), 23-74. doi: 10.1002/0470010940

Schreurs, B., \& de Laat, M. (2014). The Network Awareness Tool. A web 2.0 tool to visualize informal networked learning in organizations. Computers in Human Behavior, 37, 385-394. doi: 10.1016/j.chb.2014.04.034

Scott, J., Wasserman, S., \& Carrington, P. J. (2005). Models and methods in social network analysis. New York, NY: Cambridge University Press.

Shachar, H., \& Shmuelevitz, H. (1997). Implementing cooperative learning, teacher collaboration and teachers' sense of efficacy in heterogeneous junior high schools. Contemporary Educational Psychology, 22, 53-72.

Shoval, E., Erlich, I., \& Fejgin, N. (2010). Mapping and interpreting novice physical education teachers' self-perceptions of strengths and difficulties. Physical Education and Sport Pedagogy, 15(1), 85-101. doi: 10.1080/17408980902731350

Shrout, P.E., \& Fleiss, J.L. (1979). Intraclass correlations: Uses in assessing rater reliability. Psychological Bulletin, 86, 420-428. doi: 10.1037/0033-2909.86.2.420

Siciliano, M.D. (2016). It's the quality not the quantity of ties that matter: Social networks and self- 
efficacy beliefs. American Educational Research Journal, 53, 227-262. doi: $10.3102 / 0002831216629207$

Skaalvik, E.M., \& Skaalvik, S. (2011). Teacher job satisfaction and motivation to leave the teaching profession: Relations with school context, feeling of belonging, and emotional exhaustion. Teaching and Teacher Education, 27, 1029-1038. doi: 10.1016/j.tate.2011.04.001

Snoeck, M., Eisenschmidt, Forshuber, B., Holdsworth, P., Michaelidou, A., Dahl, J., \& Pachler, N. (2010). Developing coherent and system-wide induction programmes for beginning teachers: A handbook for policy makers. Brussels: European Commission.

Soenens, B., Sierens, E., Vansteenkiste, M., Dochy, F., \& Goossens, L. (2012). Psychologically controlling teaching: Examining outcomes, antecedents, and mediators. Journal of Educational Psychology, 104, 108-120. doi: 10.1037/a0025742

Stansbury, K., \& Zimmerman, J. (2000). Lifelines to the classroom: Designing support for beginning teachers. San Francisco, CA: West-Ed.

Stockard, J., \& Lehman, M. B. (2004). Influences on the Satisfaction and Retention of 1st-Year Teachers: The Importance of Effective School Management. Educational Administration Quarterly, 40, 742-771. doi: 10.1177/0013161X04268844

Struyve, C., Daly, A., Vandecandelaere, M., Meredith, C., Hannes, K., \& De Fraine, B. (2016). More than a mentor: The role of social connectedness in early career and experienced teachers' intention to leave. Journal of Professional Capital and Community, 1, 198-218. doi: 10.1108/JPCC-01-2016-0002

Tickle, L. (2000). Teacher induction: the way ahead. Buckingham: Open University Press. 
Toole, J.C., \& Louis, K.S. (2002). The role of professional learning communities in international education. In K. Leithwood, \& P. Hallinger (Eds.), Second international handbook of educational leadership and administration (pp. 247-279). Dordrecht: Kluwer Academics Publisher.

Tschannen-Moran, M., \& Woolfolk Hoy, A. (2001). Teacher efficacy: Capturing an elusive construct. Teaching and Teacher Education, 17, 783-805. doi: 10.1016/S0742051X(01)00036-1

Tschannen-Moran, M., \& Woolfolk Hoy, A. (2007). The differential antecedents of self-efficacy beliefs of novice and experienced teachers. Teaching and Teacher Education, 23, 944-956. doi: 10.1016/j.tate.2006.05.003

Tynjälä, P., \& Heikkinen, H.L.T. (2011). Beginning teachers' transition from pre-service education to working life: Theoretical perspectives and best practices. Zeitschrift Fur Erziehungswissenschaft, 14, 11-33. doi: 10.1007/s11618-011-0175-6

van den Broeck, A., Vansteenkiste, M., de Witte, H., Lens, W., \& Andriessen, M. (2009). De ZelfDeterminatie Theorie: Kwalitatief goed motiveren op de werkvloer [The self-determination theory: High-quality motivation in the workplace]. Gedrag en Organisatie, 22, 316-334.

Vansteenkiste, M., Neyrinck, B., Niemiec, C.P., Soenens, B., De Witte, H., \& Van den Broeck, A. (2007). On the relations among work value orientations, psychological need satisfaction, and job outcomes: A self-determination theory approach. Journal of Occupational and Organizational Psychology, 80, 251-277. doi: 10.1348/096317906X111024

Veenman, S. (1984). Perceived problems of beginning teachers. Review of Educational Research, 54, 143-178. doi: 10.3102/00346543054002143 
Vonk, J. H. C. (1995). Conceptualising novice teachers' professional development: A base of supervisory intervention. Paper presented at the annual meeting of the American Educational Research Association. San Francisco, CA.

Wang, H., Hall, N. C., \& Rahimi, S. (2015). Self-efficacy and causal attributions in teachers: Effects on burnout, job satisfaction, illness, and quitting intentions. Teaching and Teacher Education, 47, 120-130. doi: 10.1016/j.tate.2014.12.005

Wellman, B. (1983). Network analysis: Some basic principles. Sociological Theory, 1, 155-200. doi: $10.2307 / 202050$ 


\section{Tables and figures}

Table 1. Overview of the validated instruments for job satisfaction, intrinsic motivation to teach and self-efficacy.

\begin{tabular}{|c|c|c|c|c|c|c|c|c|c|c|}
\hline Measure & Author & Example item & Range & Items & CFI & TLI & RMSEA & SRMR & $\chi^{2 / \mathrm{df}}$ & $\alpha$ \\
\hline Job satisfaction & $\begin{array}{l}\text { Caprara et al. } \\
\text { (2003) }\end{array}$ & I feel good at work & $\begin{array}{l}\text { Strongly disagree }(0) \\
- \text { Strongly agree (4) }\end{array}$ & & .999 & .998 & .019 & .015 & 1.10 & .78 \\
\hline $\begin{array}{l}\text { Intrinsic } \\
\text { motivation to } \\
\text { teach }\end{array}$ & $\begin{array}{l}\text { Soenens et al. } \\
\text { (2012) based } \\
\text { on SDT (Deci } \\
\text { \& Ryan, 2000) }\end{array}$ & $\begin{array}{l}\text { I find teaching } \\
\text { enjoyable }\end{array}$ & $\begin{array}{l}\text { Strongly disagree }(0) \\
\text { - Strongly agree }(4)\end{array}$ & 4 & .928 & .911 & .071 & .066 & 2.47 & .88 \\
\hline $\begin{array}{l}\text { Teachers' self- } \\
\text { efficacy }\end{array}$ & $\begin{array}{l}\text { Tschannen- } \\
\text { Moran and } \\
\text { Woolfolk Hoy } \\
\text { (2001) }\end{array}$ & $\begin{array}{l}\text { How much can you } \\
\text { do to control } \\
\text { disruptive } \\
\text { behaviour in the } \\
\text { classroom? }\end{array}$ & $\begin{array}{l}\text { Nothing }(0)-A \\
\text { great deal (4) }\end{array}$ & 12 & .918 & .900 & .067 & .052 & 2.32 & .79 \\
\hline
\end{tabular}

Note: The instrument of Caprara, Barbaranelli, Borgogni, \& Steca (2003) was chosen because it measures teachers' overall sense of job satisfaction, rather than satisfaction with particular aspects of the job (Skaalvik \& Skaalvik, 2011). 


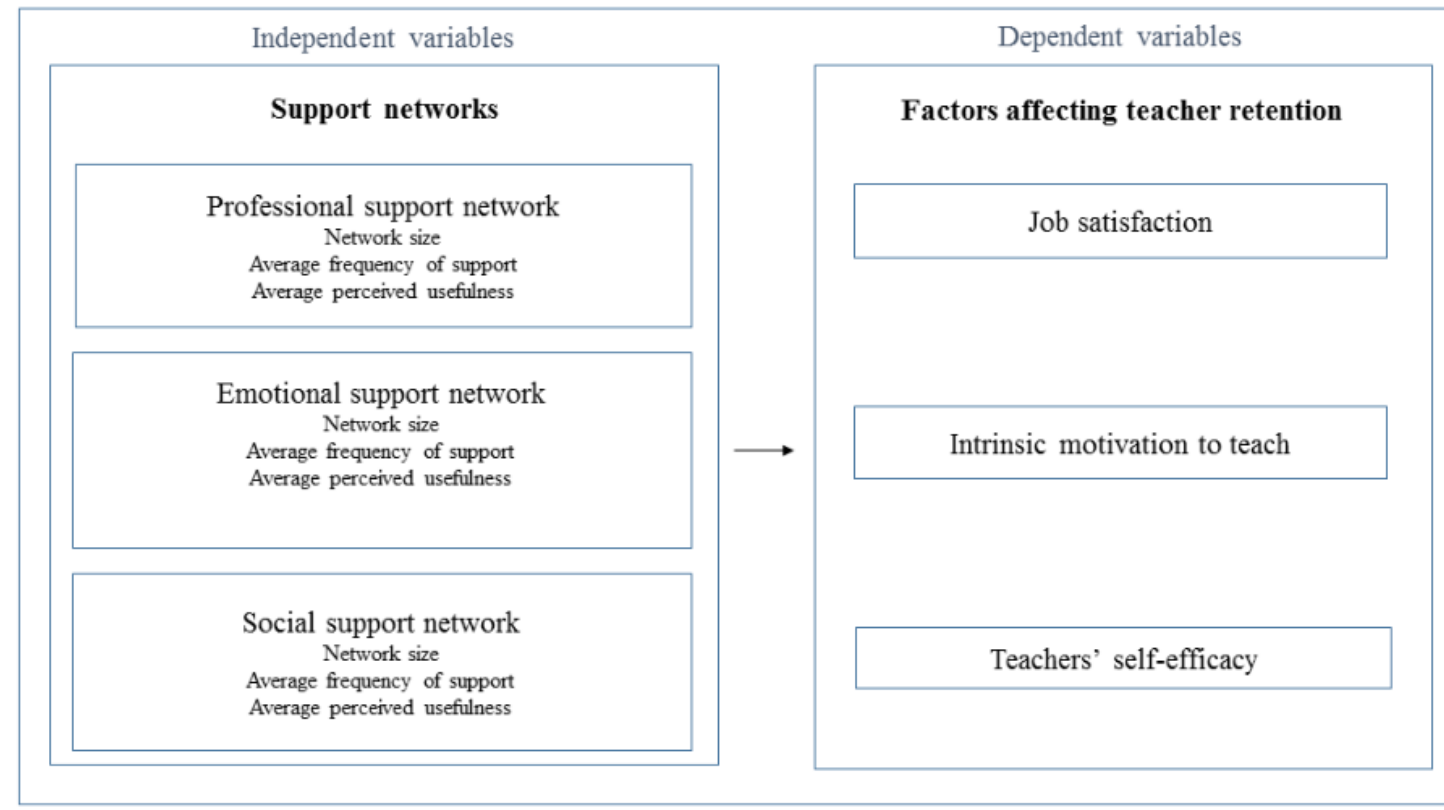

Figure 1. Scope of the study 
Table 2. Descriptives on the three types of support networks.

\begin{tabular}{|c|c|c|c|}
\hline & $\begin{array}{c}\text { Professional } \\
\text { support }\end{array}$ & $\begin{array}{l}\text { Emotional } \\
\text { support }\end{array}$ & $\begin{array}{l}\text { Social } \\
\text { support }\end{array}$ \\
\hline \multicolumn{4}{|l|}{ Tie analysis } \\
\hline Average network size $M(S D)$ & $5.72(3.22)$ & $5.61(3.51)$ & $5.97(3.64)$ \\
\hline Average frequency of support $M(S D)$ & $2.94(.78)$ & $2.69(.88)$ & $2.91(.97)$ \\
\hline Average perceived usefulness $M(S D)$ & $4.46(.50)$ & $4.36(.66)$ & $4.43(.63)$ \\
\hline \multicolumn{4}{|l|}{ Alter analysis } \\
\hline \multicolumn{4}{|l|}{ Average $\%$ of gender } \\
\hline Male $(\mathrm{M})$ & $14.00 \%$ & $11.36 \%$ & $12.71 \%$ \\
\hline \multirow[t]{7}{*}{ Female (F) } & $86.00 \%$ & $88.64 \%$ & $87.29 \%$ \\
\hline & $\underline{\text { Female ego }}$ & $\underline{\text { Female ego }}$ & $\underline{\text { Female ego }}$ \\
\hline & $13.83 \% \mathrm{M}$ & $11.61 \% \mathrm{M}$ & $12.72 \% \mathrm{M}$ \\
\hline & $86.17 \% \mathrm{~F}$ & $88.39 \% \mathrm{~F}$ & $87.28 \% \mathrm{~F}$ \\
\hline & Male ego & $\underline{\text { Male ego }}$ & $\underline{\text { Male ego }}$ \\
\hline & $15.36 \% \mathrm{M}$ & $9.33 \% \mathrm{M}$ & $12.64 \% \mathrm{M}$ \\
\hline & $84.64 \% \mathrm{~F}$ & $90.67 \% \mathrm{~F}$ & $87.36 \% \mathrm{~F}$ \\
\hline \multicolumn{4}{|l|}{ Homogeneity } \\
\hline Experience of alters $M(S D)$ & $16.68(6.38)$ & $16.44(6.18)$ & $16.78(6.62)$ \\
\hline \multirow[t]{5}{*}{ Average Blau's H (IQV) for gender } & $.17(.33)$ & $.15(.30)$ & $.16(.31)$ \\
\hline & $\underline{\text { Female ego }}$ & $\underline{\text { Female ego }}$ & $\underline{\text { Female ego }}$ \\
\hline & $.16(.32)$ & $.15(.31)$ & $.17(.33)$ \\
\hline & Male ego & Male ego & Male ego \\
\hline & $.20(.39)$ & $.14(.28)$ & $.15(.31)$ \\
\hline \multicolumn{4}{|l|}{ Homophily } \\
\hline Average absolute differences for experience $M(S D)$ & $15.74(6.38)$ & $15.50(6.18)$ & $15.85(6.62)$ \\
\hline \multirow[t]{5}{*}{ Average EI-index for gender } & -.57 & -.59 & -.58 \\
\hline & $\underline{\text { Female ego }}$ & $\underline{\text { Female ego }}$ & $\underline{\text { Female ego }}$ \\
\hline & -.72 & -.77 & -.75 \\
\hline & $\underline{\text { Male ego }}$ & $\underline{\text { Male ego }}$ & $\underline{\text { Male ego }}$ \\
\hline & .69 & .81 & .75 \\
\hline
\end{tabular}

Note: $\mathrm{M}=$ average. $\mathrm{SD}=$ standard deviation. Frequency was measured with 1='3-monthly', 2='monthly', 3='weekly', 4='multiple times a week', 5='daily'. Perceived usefulness was measured with $1={ }^{\prime}$ never useful', 2='not useful most of the time', $3=$ 'useful some of the time', 4='useful most of the time', 5='always useful'. Blau's heterogeneity index measures the similarity among the ego's alters and varies between 0 (homogeneity) and 1-(1/r) (heterogeneity) with $\mathrm{r}$ as the number of categories. Between brackets the IQV (index for Qualitative Variation) is reported, which is a normalised version of the Blau's H index and ranges from 0 (homogeneity) to 1 (heterogeneity). EI-index measures the extent to which the ego's alters are similar to the ego for a specific characteristic and ranges from +1 (heterophily) to -1 (homophily). 
Table 3. Descriptives on job satisfaction, intrinsic motivation to teach and self-efficacy.

\begin{tabular}{lcc}
\hline & Mean & Standard deviation \\
\hline Job satisfaction & 3.35 & .55 \\
Intrinsic motivation to teach & 3.35 & .53 \\
Self-efficacy & 2.67 & .41 \\
\hline
\end{tabular}

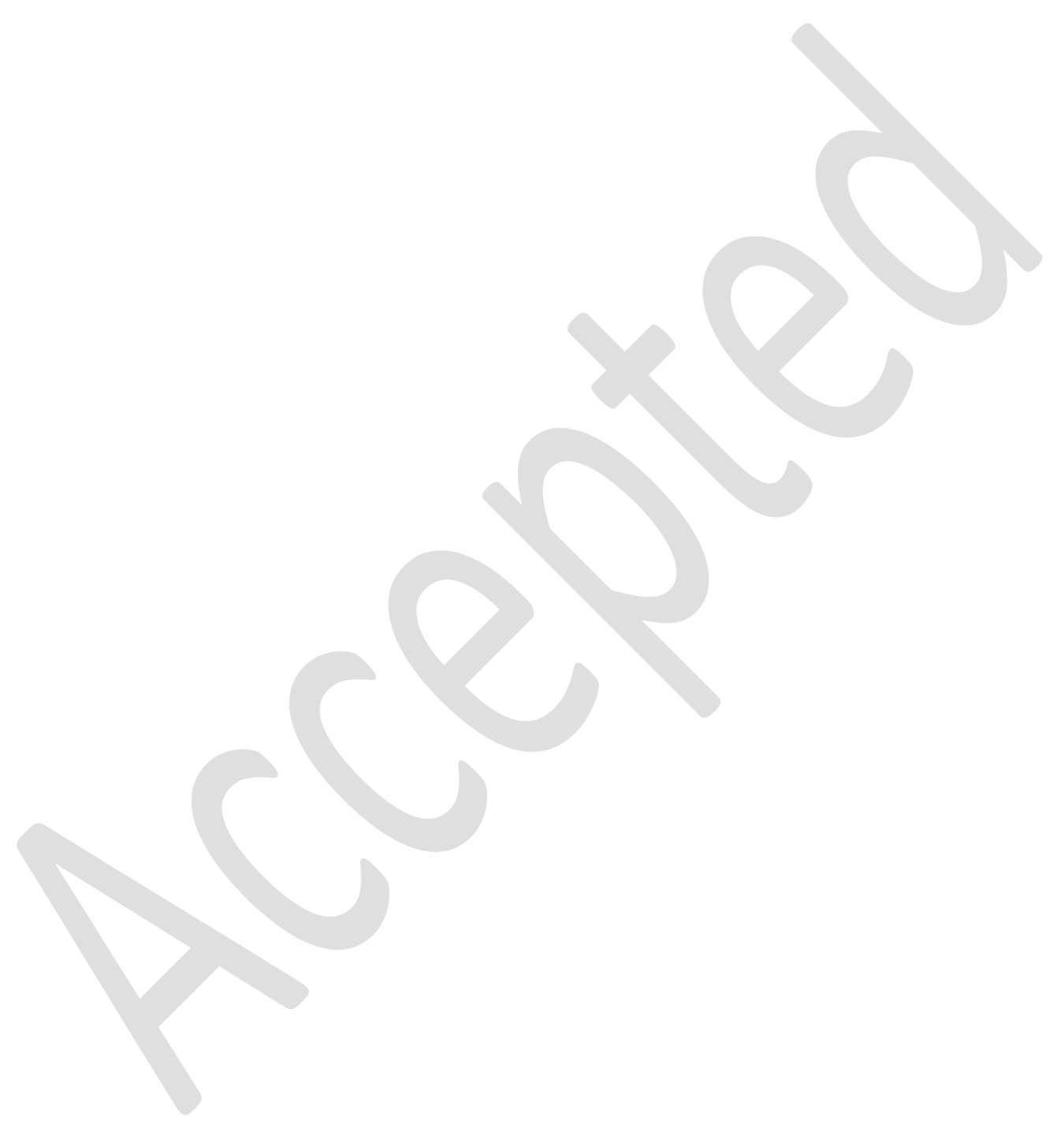


Table 4. Final regression models of relationships between support, and job satisfaction, intrinsic motivation to teach and self-efficacy

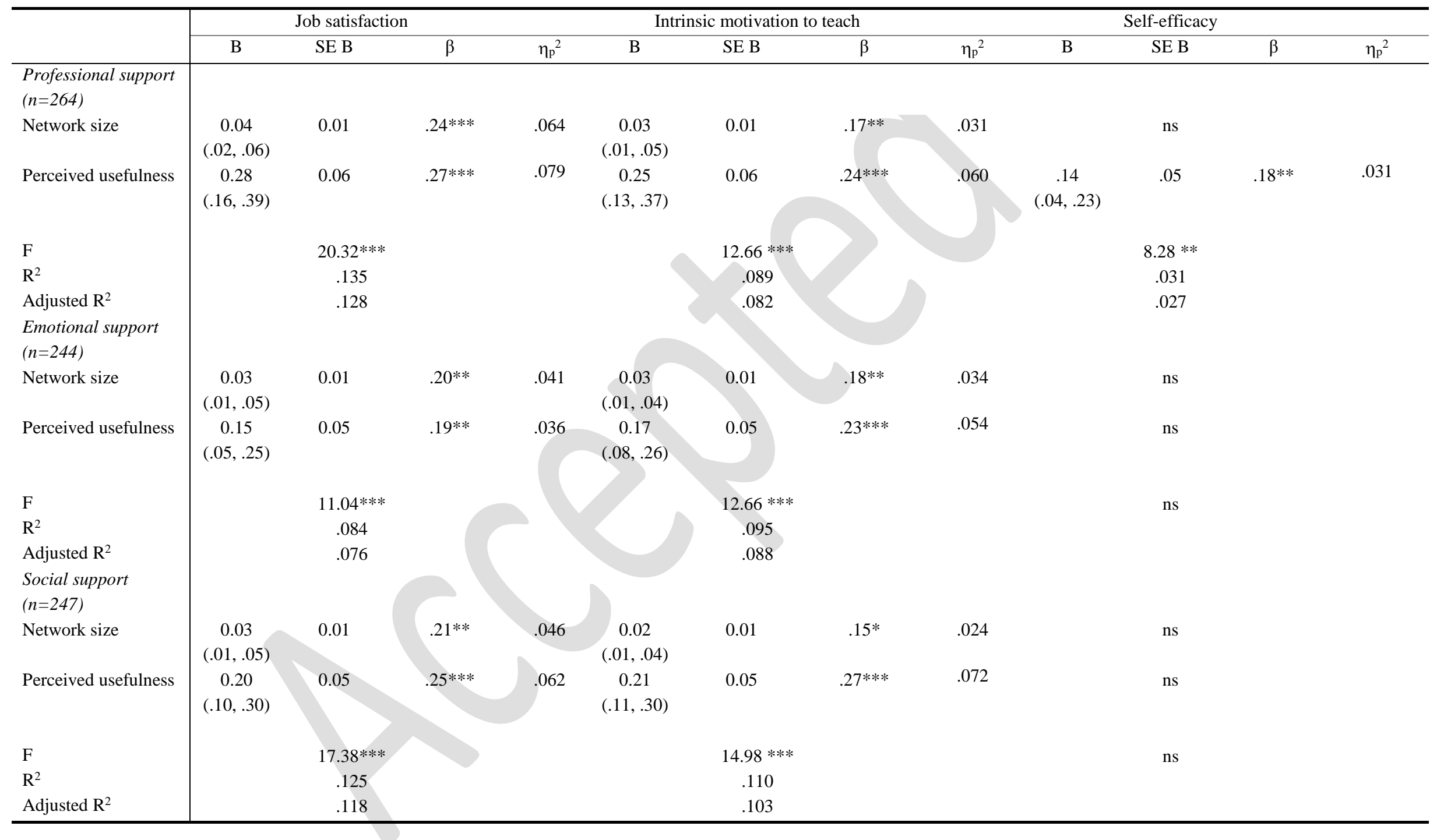

Note: $*<.05 ; * *<.01 ; * * *<.001 ;$ ns=not significant; The sample size for the regression models differs based on the number of respondents that completed all relevant parts of the questionnaire. 
Appendix. Excerpt of the online survey

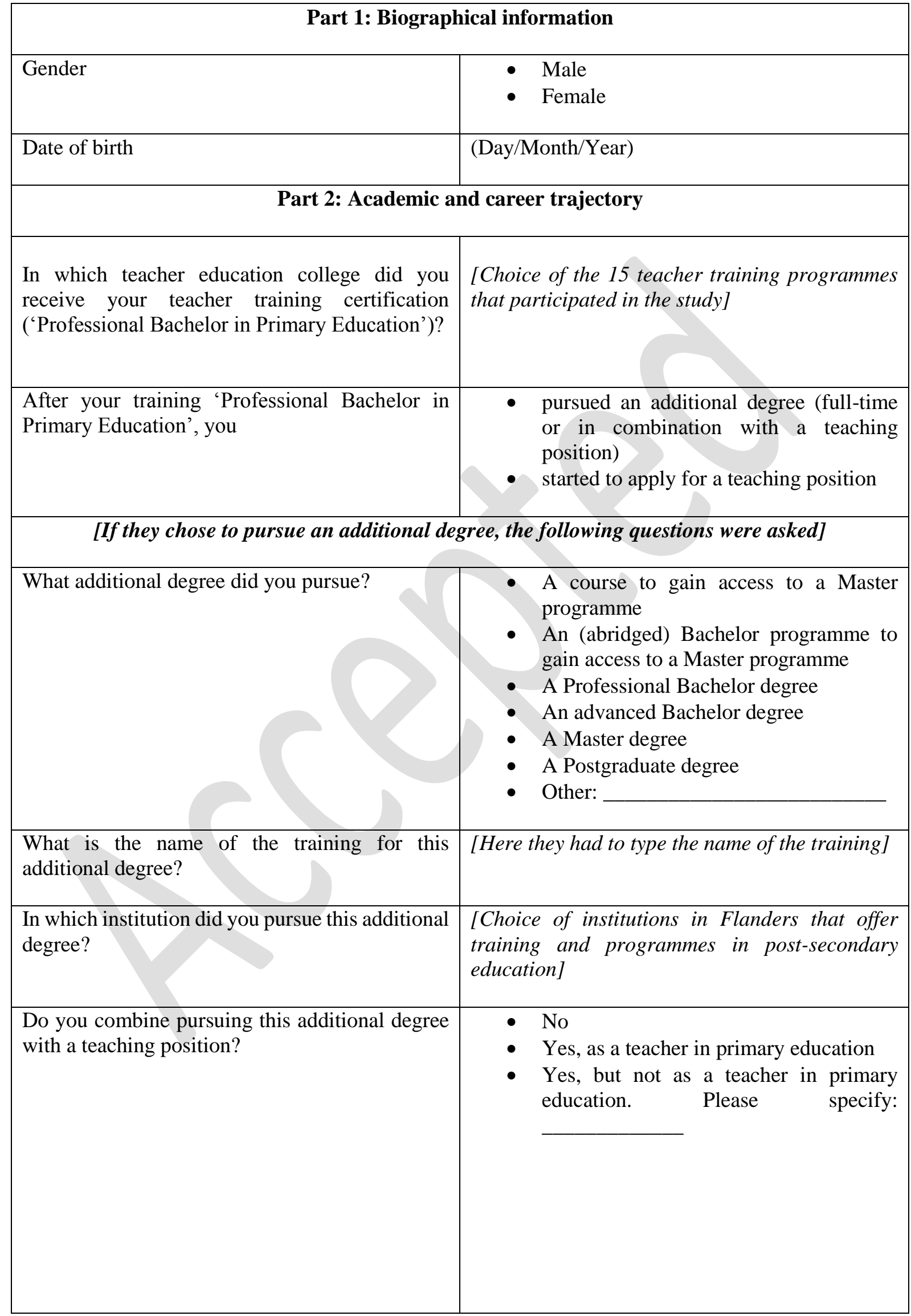


Appendix. Excerpt of the online survey [continued]

\begin{tabular}{|c|c|}
\hline \multicolumn{2}{|c|}{ [If they chose to start applying for a job, the following question was asked] } \\
\hline Please check the box that applies to your situation & 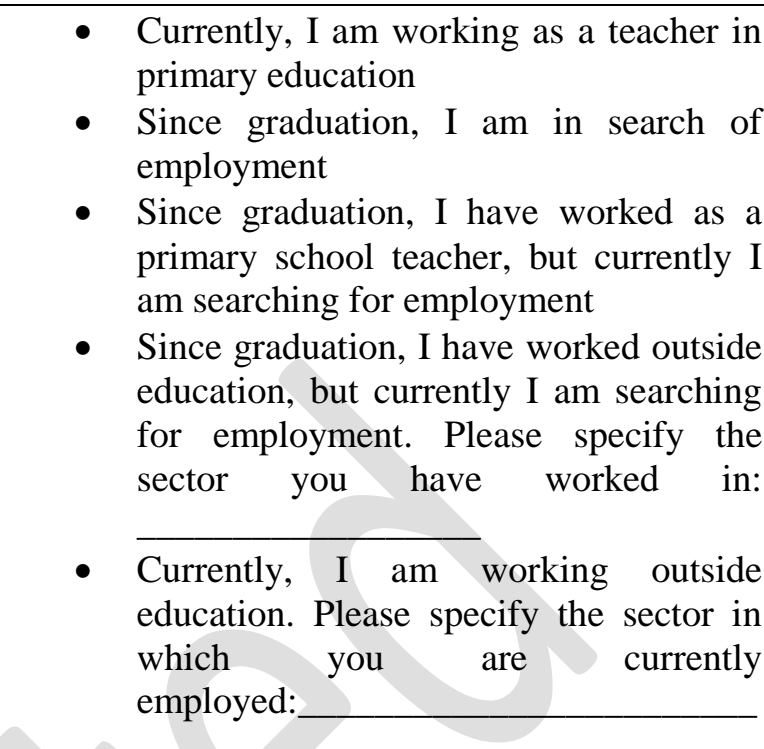 \\
\hline \multicolumn{2}{|c|}{$\begin{array}{l}\text { Additional questions regarding career trajectory for those participants with a teaching job } \\
\text { [Note: From here on, the survey only continues for (1) those participants who follow an additional } \\
\text { training but combine this training with a job as a primary school teacher, and (2) those participants } \\
\text { who after graduation applied for a job and are currently working as a primary school teacher } \\
(n=292) .]\end{array}$} \\
\hline $\begin{array}{l}\text { In how many schools have you worked as a } \\
\text { primary school teacher since graduation? (your } \\
\text { current school(s) included) }\end{array}$ & [number of schools] \\
\hline In how many schools are you currently working? & [number of schools] \\
\hline $\begin{array}{l}\text { What is the number of working hours }[\mathrm{FTE}] \text { in } \\
\text { your current school(s)? }\end{array}$ & $\begin{array}{l}\text { - Full-time } \\
\text { - Part-time } \\
\text { Specify the number of working hours: } \\
\text { [This was repeated if they work in more than one } \\
\text { school] }\end{array}$ \\
\hline $\begin{array}{l}\text { When your current contract ends, how likely is it } \\
\text { that you will be able to keep a teaching position } \\
\text { in your current school(s)? }\end{array}$ & $\begin{array}{l}\text { - Certainly } \\
\text { - Probably } \\
\text { - Unlikely } \\
\text { - I will not be able to keep my position } \\
\text { - I don't know }\end{array}$ \\
\hline $\begin{array}{l}\text { When your current contract ends, are you already } \\
\text { guaranteed a contract in another school? }\end{array}$ & $\begin{array}{ll}\text { - } & \text { Yes } \\
\text { - } & \text { No }\end{array}$ \\
\hline
\end{tabular}


Appendix. Excerpt of the online survey [continued]

\section{Part 3: Experiences concerning being a teacher, the teaching profession and your school(*)}

${ }^{*}$ ) If you are currently working at more than one school, we ask you to report about the school where you teach the largest number of hours.

Check the box that represents your opinion.

\section{$\underline{\text { Job satisfaction }}$}

- I am satisfied with my job

- I am happy with the way my colleagues and superiors treat me

- I am satisfied with what I achieve at work

- I feel good at work

\section{$\underline{\text { Intrinsic motivation to teach }}$}

- I am very interested in teaching

- Teaching is fun

- I find teaching enjoyable

- I find teaching a pleasant activity

\section{Teachers' self-efficacy}

- How much can you do to control disruptive behavior in the classroom?

- How much can you do to motivate students who show low interest in school work?

- How much can you do to get students to believe they can do well in school work?

- How much can you do to help your students value learning?

- To what extent can you craft good questions for your students?

- How much can you do to get children to follow classroom rules?

- How much can you do to calm a student who is disruptive or noisy?

- How well can you establish a classroom management system with each group of students?

- How much can you use a variety of assessment strategies?

- To what extent can you provide an alternative explanation or example when students are confused?

- How much can you assist families in helping their children do well in school?

- How well can you implement alternative strategies in your classroom?
For job satisfaction and intrinsic motivation to teach, respondents could answer each item using the following scale:

0) Strongly disagree

1) Disagree

2) Agree nor disagree

3) Agree

4) Stronglyagree

For teachers 'self-efficacy, respondents could answer each item using the following scale:
0) Nothing
1) Very little
2) Some
3) Quite a bit
4) A great deal 
Appendix. Excerpt of the online survey [continued]

\section{Part 4: Your support networks at school}

In this part of the survey, we have some questions about the people that support you at school (*).

(*) Again, we are asking you that, if you are currently working at more than one school, you report about the school where you teach the largest number of hours; the school you reported about earlier in part 3

\begin{tabular}{|c|c|}
\hline \multicolumn{2}{|c|}{ Name generator } \\
\hline $\begin{array}{l}\text { From which of your colleagues do you receive } \\
\text { professional support? } \\
\text { Professional support is support that helps you } \\
\text { develop the required competences and grow } \\
\text { professionally. E.g., help with the pedagogical } \\
\text { aspects of teaching such as classroom } \\
\text { management, advice about didactics and } \\
\text { teaching practices and exchanging teaching } \\
\text { materials. }\end{array}$ & \\
\hline You can name up to 20 colleagues. & \\
\hline $\begin{array}{l}\text { From which of your colleagues do you receive } \\
\text { emotional support? } \\
\text { Emotional support is support in which you are } \\
\text { helped to overcome the praxis shock, from } \\
\text { colleagues who guide you through the difficulties } \\
\text { you experience. Think about colleagues that } \\
\text { encourage you or affirm/praise your work. }\end{array}$ & $\begin{array}{l}\text { [For each of these questions the participants } \\
\text { were asked to create a unique code for each } \\
\text { colleague. They could work with colleagues' first } \\
\text { name, initials, or another code that would work } \\
\text { for them. Respondents could name up to } 20 \\
\text { colleagues, a smaller number was also possible] }\end{array}$ \\
\hline You can name up to 20 colleagues. & \\
\hline $\begin{array}{l}\text { From which of your colleagues do you receive } \\
\text { social support? } \\
\text { Social support is support in which colleagues } \\
\text { help you to become part of the team, and help you } \\
\text { adjust to the specific school's culture. For } \\
\text { example, teachers that include you in the team, } \\
\text { and provide you with information about school } \\
\text { rules, habits, guidelines and procedures. }\end{array}$ & \\
\hline & \\
\hline
\end{tabular}


Appendix. Excerpt of the online survey [continued]

\begin{tabular}{|c|c|}
\hline \multicolumn{2}{|c|}{$\begin{array}{l}\text { Name interpreter } \\
\text { [From each of the colleagues the participant mentioned in the name generator phase, the following } \\
\text { interpreting questions were asked] }\end{array}$} \\
\hline Gender & $\begin{array}{ll}- & \text { Male } \\
\text { - } & \text { Female } \\
\end{array}$ \\
\hline $\begin{array}{l}\text { How many years of educational experience does } \\
\text { this colleague have, according to your } \\
\text { estimation? }\end{array}$ & [number of years] \\
\hline $\begin{array}{l}\text { For each of the colleagues that offer professional } \\
\text { support: }\end{array}$ & $\begin{array}{l}\text { Respondents could answer using the following } \\
\text { scale: }\end{array}$ \\
\hline $\begin{array}{l}\text { - How frequently do you receive professional } \\
\text { support from this colleague? }\end{array}$ & $\begin{array}{l}\text { 1) Once every three months } \\
\text { 2) monthly } \\
\text { 3) weekly } \\
\text { 4) multiple times a week } \\
\text { 5) daily }\end{array}$ \\
\hline $\begin{array}{l}\text { - How useful do you perceive the professional } \\
\text { support from this colleague? }\end{array}$ & $\begin{array}{l}\text { 1) Never useful } \\
\text { 2) not useful most of the time } \\
\text { 3) useful some of the time } \\
\text { 4) useful most of the time } \\
\text { 5) always useful }\end{array}$ \\
\hline $\begin{array}{l}\text { For each of the colleagues that offer emotional } \\
\text { support: }\end{array}$ & $\begin{array}{l}\text { Respondents could answer using the following } \\
\text { scale: }\end{array}$ \\
\hline $\begin{array}{l}\text { - How frequently do you receive emotional } \\
\text { support from this colleague? }\end{array}$ & $\begin{array}{l}\text { 1) Once every three months } \\
\text { 2) monthly } \\
\text { 3) weekly } \\
\text { 4) multiple times a week } \\
\text { 5) daily }\end{array}$ \\
\hline $\begin{array}{l}\text { - How useful do you perceive the emotional } \\
\text { support from this colleague? }\end{array}$ & $\begin{array}{l}\text { 1) Never useful } \\
\text { 2) not useful most of the time } \\
\text { 3) useful some of the time } \\
\text { 4) useful most of the time } \\
\text { 5) always useful }\end{array}$ \\
\hline $\begin{array}{l}\text { For each of the colleagues that offer social } \\
\text { support: }\end{array}$ & $\begin{array}{l}\text { Respondents could answer using the following } \\
\text { scale: }\end{array}$ \\
\hline $\begin{array}{l}\text { - How frequently do you receive social support } \\
\text { from this colleague? }\end{array}$ & $\begin{array}{l}\text { 1) Once every three months } \\
\text { 2) monthly } \\
\text { 3) weekly } \\
\text { 4) multiple times a week } \\
\text { 5) daily }\end{array}$ \\
\hline $\begin{array}{l}\text { - How useful do you perceive the social } \\
\text { support from this colleague? }\end{array}$ & $\begin{array}{l}\text { 1) Never useful } \\
\text { 2) not useful most of the time } \\
\text { 3) useful some of the time } \\
\text { 4) useful most of the time } \\
\text { 5) always useful }\end{array}$ \\
\hline
\end{tabular}

